\title{
Water Quality Dynamics of Ephemeral Wetlands in the Piedmont Ecoregion, South Carolina, USA
}

\author{
Alex T. Chow ${ }^{1,2^{*}}$, Amber L. Pitt ${ }^{3}$, Robert F. Baldwin ${ }^{1}$, \\ Dennis Suhre ${ }^{1}$, and Jun-Jian Wang ${ }^{4}$
}

1: Department of Forestry \& Environmental Conservation, Clemson University, SC 29634

2: Department of Environmental Engineering \& Earth Science, Clemson University, SC 29634

3: Environmental Science Program and Department of Biology, Trinity College, Hartford, CT 06106

4: Department of Physical and Environmental Sciences, University of Toronto, ON M1C 1A4, Canada

* Corresponding Author,

Mail address: PO Box 596, Georgetown, SC 29442;

Email: achow@clemson.edu;

Phone: 843-546-1013 ext 232;

Fax: 843-546-6296 


\section{Abstract}

Small ephemeral wetlands are commonly found in the Piedmont ecoregion of the southeastern USA. Ephemeral wetlands have important ecological functions but information about their water quality over its flooding periods is relatively limited. In this study, the water chemistry and physical parameters of three ephemeral wetlands and their nearby water bodies, including first order and second order streams and groundwater in the Piedmont ecoregion of South Carolina, were closely monitored during their flooding periods from January to June 2012. Nutrient and water quality analyses demonstrated the chemistries of wetlands, stream, and groundwater were different from each other in spite of their proximity. Greater concentrations of dissolved organic carbon (DOC) and dissolved organic nitrogen with a major portion in humic acid-like and fulvic acid-like fractions was generally found in wetland waters. In contrast, significantly lower DOC concentrations with a greater portion of inorganic nitrogen were observed in stream and groundwater. Electrical conductivity at $25{ }^{\circ} \mathrm{C}\left(\mathrm{EC}_{25}\right)$ and temperature measurements showed a greater fluctuation in wetlands, indicating their poor buffering capacity against environmental changes. Results of this field study suggested that these small ephemeral wetlands in the Piedmont Ecoregion having relatively unique biogeochemistry in comparing their adjacent water bodies.

Key Words: Dissolved organic carbon, dissolved organic matter, isolated wetland, nutrient, seasonal wetland 


\section{Introduction}

Ephemeral wetlands (i.e., isolated, seasonal, temporary, dry end, or headwater wetlands; vernal pools) provide numerous watershed-level functions including critical wildlife habitat, floodwater storage, groundwater recharge, and water filtration. Global declines in ephemeral wetlands have been linked to amphibian declines, loss of habitat for reptiles and invertebrates, and alterations to hydrological regimes (Gibbons et al. 2000, Jenkins et al. 2003, Zedler and Kercher 2005). Smaller wetlands are less able to recover functions after human disturbance (Moreno-Mateos et al. 2012), yet because of their dispersion in the landscape provide value disproportionate to their size (Gibbs 1993, Leibowitz 2003). Despite the importance of these wetlands, they are poorly protected in much of the United States and have, at best, ambiguous levels of regulatory oversight under the CWA (Zedler 2003). U.S. Supreme Court decisions (e.g., Rapanos et ux, et al. v. United States, 547 U.S. 715, 2006) suggested that water bodies other than traditional navigable waters (TNWs) and the adjacent wetlands and relative permanent tributaries of TNWs and the abutting wetlands could be jurisdictional waters if a significant nexus based on hydrological or ecological connectivity existed with a TNW (Grumbles and Woodley 2008). A recent U.S. rule expands definition of waters of the United States and establishes a pressing need for better scientific information to define connectivity among water bodies (Federal Register, 2014). The Piedmont ecoregion of the southeastern United States is a useful instance of loss of wetlands to historical agriculture that had intensive impacts on geomorphology of aquatic systems; such have been compounded by recent urbanization and land-use changes (Campbell et al. 2008, Napton et al. 2010). The extent of wetland loss is largely unknown and, until recently, few small, ephemeral, 'isolated' wetlands in the Piedmont ecoregion had been mapped, let alone studied (Pitt et al. 2012). Population growth, land use trends, and the resultant pressure on 
wetlands and other aquatic resources have created a need to better understand small, ephemeral, 'isolated' wetlands.

Different methods and characteristics have been used to examine the connectivity of wetlands and their nearby water bodies, including physical measurements i.e., water level and temperature, (Cabezas et al. 2011; Glinska-Lewczuk, 2009), chemical parameters such as nitrogen and phosphorus (Wolf et al. 2013; Glinska-Lewczuk, 2009), biological indicators such as macrozoobenthos patterns (Obolewski 2011), as well as mathematical modeling (Golden et al. 2014). These methods, generally used in floodplain or riparian wetlands, may not be directly applicable to more geographically isolated, ephemeral wetlands in the Piedmont ecoregion because of the wetlands' unique physical characteristics including small size, shallow depth, and relatively short hydroperiod.

In order to understand the connectivity and ecological function of Piedmont ephemeral wetlands, we first need to understand their water quality dynamics through the entire hydroperiod. In this study, we examined the water chemistry and physical parameters of three ephemeral wetlands and the nearby water bodies between 26 January and 5 June 2012, a time period that encompassed the typical flooded period of ephemeral wetlands in Piedmont ecoregion of the southeastern United States. In addition to general water quality and nutrient analyses, we introduce the use of optical properties of dissolved organic matter (DOM) to examine ephemeral wetland biogeochemistry compared to nearby water bodies. DOM produced from different sources has a unique optical signature in ultraviolet and visible light absorption and fluorescence spectra and has been used in source-water tracking (Osburn et al. 2012; Chow et al. 2008). We 
hypothesized that small, ephemeral, 'isolated' wetlands have unique biogeochemical characteristics in comparing with nearby permanent water bodies which had different hydrology. We designed our study to contribute to the growing understanding of how to evaluate chemical relationships among water bodies in the context of "Significant Nexus".

\section{Materials and Methods}

\subsection{Study Sites}

We selected two index landscapes within the Piedmont ecoregion of South Carolina, USA (Figures 1a and 1b). The first index landscape contained a first order stream, two ephemeral wetlands with varying degrees of geographic isolation, and a cypress swamp with surficial hydrological connections with the stream and a lake. Site A within the first index landscape (Figure 1c) had the smallest ephemeral wetland with a maximum surface area of $6.75 \mathrm{~m}^{2}$ and it was approximately $10.7 \mathrm{~m}$ from the perennial stream. The ephemeral wetland in site B (Figure 1c) of the first index landscape had a maximum surface area of $37.74 \mathrm{~m}^{2}$ and was adjacent to a formerly ephemeral wetland that became permanent and surficially hydrologically connected with the stream due to beaver damming activity. Site B also contained the cypress swamp with surficial hydrological connections to the stream and lake (Figure 1c). The second index landscape contained site C (Figure 1d) which included a second order stream, an ephemeral floodplain wetland, and a marsh with surficial hydrological connections with a lake. The wetland in site $\mathrm{C}$ had a maximum surface area of $2444.0 \mathrm{~m}^{2}$, excluding the areas that became flooded for a short duration $(\leq 1$ week) during flooding events of the adjacent stream.

\subsection{Piezometer Construction and Water Level Measurement}


Piezometers were installed on $8-10$ January 2012 in order to sample groundwater. The locations of the piezometers were selected based on their relative positions between the ephemeral wetlands and nearby streams (Figures SI-1 - SI-3, as available in Supplementary Information [SI]). For constructing a piezometer, a $15 \mathrm{~cm}$-diameter x $50 \mathrm{~cm}$-depth borehole was drilled. A $1 \mathrm{~m}$-long x $5 \mathrm{~cm}$-diameter PVC pipe was placed in the borehole. The bottom of the PVC pipe was capped with a slotted screen $30 \mathrm{~cm}$ from the bottom. Gravel was placed around the slotted interval and bentonite was added on top to prevent water infiltrating from the soil surface. Levels of groundwater (denoted as G) were manually measured using a portable water level meter. Depths of wetlands (denoted as W) and streams (denoted as S) at selected locations were determined manually using meter sticks. Rain gauges (denoted as R) were placed in each site for precipitation determination. There are a total 9 sampling points in Site A (i.e. 5 groundwater denoted as A-G1 to A-G5; 2 wetland waters denoted as A-W1 and A-W2; 2 stream waters denoted as A-S1 and A-S2), 13 sampling points in Site B (i.e. 5 groundwater denoted as B-G1 to B-G5; 5 wetland waters denoted as B-W1 to B-W5; 3 stream waters denoted as B-S1 to B-S3), 16 sampling points in site C (i.e. 10 groundwater denoted as C-G1 to C-G10; 3 wetland waters denoted as $\mathrm{C}-\mathrm{W} 1$ to $\mathrm{C}-\mathrm{W} 3 ; 3$ stream waters denoted as $\mathrm{C}-\mathrm{S} 1$ to $\mathrm{C}-\mathrm{S} 3$ ). Measurements were conducted at least three times per week during the study period. Rates of change in water level or water depth $(\Delta \mathrm{h} / \Delta \mathrm{t})$ at each point were calculated by dividing the difference between two measurements by the time interval.

\subsection{Water Quality Determination}

General water quality of stream and wetland waters was determined using YSI 556 Multiprobe System equipped with dissolved oxygen (DO), $\mathrm{pH}$, electrical conductivity corrected to $25{ }^{\circ} \mathrm{C}$ 
$\left(\mathrm{EC}_{25}\right)$, turbidity, oxidation-reduction potential (ORP), and temperature sensors (YSI, Inc., Yellow Springs, OH, USA). The probe was gently placed $5-10 \mathrm{~cm}$ below the water surface to minimize any disturbance of wetland sediments. Measurements were generally taken between 0900-1500 hrs and these field surveys were conducted at least three times per week. Grab samples were collected once a month for nutrient analysis and dissolved organic matter (DOM) characterization (section 3.4). Surface water, approximately $5 \mathrm{~cm}$ below the water's surface, was collected in $125 \mathrm{~mL}$ pre-acid washed polyethylene bottles. Soil pore water was manually pumped from the pre-installed piezometers (section 3.2). At least one liter of water was pumped and discarded from the piezometer before collecting into a $125 \mathrm{~mL}$ bottle. Each sample type (i.e., wetland, stream, and ground water) had at least two sampling spots and 3 sampling months, the sample size was always $\geq 6$. All samples were immediately stored in an ice cooler and transported to the laboratory. Waters were then filtered through $0.45 \mu \mathrm{m}$ membrane filters (Millipore Express PLUS Membrane, polyethersulfone, hydrophilic, $47 \mathrm{~mm}$ ). Filtrates were then stored at $4^{\circ} \mathrm{C}$ until further analysis. All measurements and samples were collected between 26 January and 15 June 2012. Water quality measurements ended when the ephemeral wetlands were dry. Only one wetland in site B was fully examined for six months. The wetlands in sites A and C (Figures 1c and d) were completely dry in April.

\subsection{Chemical Analysis}

Each filtered sample was analyzed for dissolved organic carbon (DOC) and total dissolved nitrogen (TDN) using a Shimadzu TOC/TN analyzer. Inorganic $\mathrm{N}$, including $\mathrm{NH}_{4}-\mathrm{N}$ and $\left(\mathrm{NO}_{2}+\mathrm{NO}_{3}\right)-\mathrm{N}$ were determined using a Systea ${ }^{\circledR}$ Easychem ${ }^{\mathrm{TM}}$ discrete analyzer (EPA Methods 350.1 and 325.2, respectively; Eaton et al. 2005). DOC was further characterized by Shimadzu 
UV-1800 visible and ultraviolet spectrophotometer scanning from $200-700 \mathrm{~nm}$. Specific ultraviolet absorbance (SUVA) was calculated by normalizing ultraviolet absorbance at $254 \mathrm{~nm}$ to

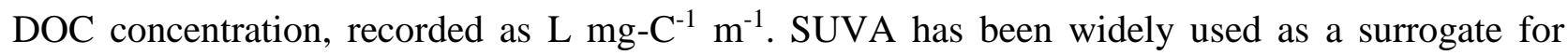
aromatic carbon content of DOC (Chow et al., 2008). Spectral slope ratio $\left(\mathrm{S}_{\mathrm{R}}\right)$, which is correlated with molecular weight (MW) of DOC and to photochemically induced shifts in MW, was calculated as the ratio of two spectral slopes between 275-295 nm and 350-400 nm (Helms et al. 2008; Loiselle et al. 2009). In addition, the E2/E3 ratio, absorbance at $254 \mathrm{~nm}$ (E2) divided by absorbance at $365 \mathrm{~nm}$ (E3), was calculated. The E2/E3 ratio, which is positively correlated with the quantum yields of singlet oxygen $\left({ }^{1} \mathrm{O}_{2}\right)$ but negatively correlated with hydrogen peroxide $\left(\mathrm{H}_{2} \mathrm{O}_{2}\right)$ (Dalrymple et al., 2010), is an important index showing the photo-degradability and photoreactivity of DOC. Selected samples were further analyzed using fluorescence emission-excitation matrix (EEM). The components and redox index of DOC were quantified using the fluorescence regional integration (FRI) model that separate into aromatic protein I, aromatic protein II, fulvic acid-like, and microbial byproduct-like, and humic acid-like fractions (Zhou et al., 2013). Samples were diluted with deionized water to the absorbance at $254 \mathrm{~nm}$ to 0.3 or lower, and were measured using a Shimadzu RF-5301 spectrofluorophotometer. Ultraviolet-visible (UV/VIS) and fluorescence spectroscopy have been used to track the origins and the sources of DOM in water (Chow et al. 2008; Osburn et al. 2012). Specific ultraviolet absorbance (SUVA) was calculated by

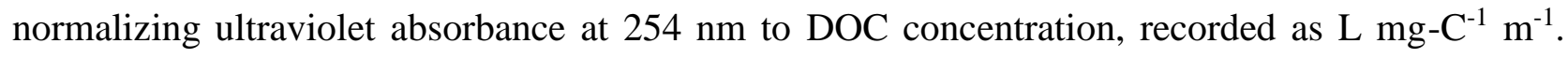
SUVA has been widely used as a surrogate of aromatic carbon content of DOC (Chow et al. 2008).

\subsection{Statistical Analyses}


Water quality parameters among different water bodies were compared using a paired-samples $t$ test. In addition to the average and 95\% confidence limits of measured values, daily differences were calculated in order to eliminate the seasonal effects. Parameters of two water bodies were considered the same if their differences were not significantly different from zero. For those parameters that did not conform to a normal distribution (Kolmogorov-Smirnov test) and homogeneity of variance (Levene test), a Wilcoxon signed rank test was used. To detect differences in water quality parameters at different times, ANOVA and a post-hoc Tukey's test were used unless the non-parametric comparison was specified. A Kruskal -Wallis test and a non-parametric Tukey-type multiple comparisons test were used when parameters did not conform to a normal distribution and homogeneity of variance. Statistical methods were implemented using SPSS version 19.0 (IBM Corporation, Armonk, NY, USA) and the level of significance was $\alpha=0.05$.

\section{Results}

\subsection{Water Level and Hydroperiod}

The wetland in site A had the smallest surface area $\left(6.75 \mathrm{~m}^{2}\right)$ but the greatest water depth $(40.3$ $\mathrm{cm})$; it was inundated for approximately 4 months and was completely dry by late April. The wetland in site B had a surface area of $37.74 \mathrm{~m}^{2}$ with a water depth of $34.8 \mathrm{~cm}$. The wetland was inundated for over 6 months and was still flooded at the end of the study period (15 June 2013). The wetland in site $\mathrm{C}$ had the largest surface area of the three studied wetlands $\left(2444 \mathrm{~m}^{2}\right)$ but the shallowest depth $(27.1 \mathrm{~cm})$. Most of the area in this wetland was dry in early February but some areas were still flooded until late April. 
The water levels of these wetland systems were generally sensitive to precipitation. Rapid increases in water levels were observed during rainstorms. For example, sudden increases of water levels in groundwater and wetland were observed in site A on 3 March, 17 April, and 15 May, when intensive rainstorms (> $0.5 \mathrm{~mm}$ per day) occurred (Figure 2). Notably, both groundwater and wetland levels showed similar magnitude of changes. Following rain events, they each rapidly dropped back to their background levels. Although there were slight increases in water depth of nearby streams, the levels varied $<10 \%$ during the 6-month study period.

Correlation coefficient matrixes among the rates of change in water level $(\Delta \mathrm{h} / \Delta \mathrm{t})$ calculated from different sampling points were compared and summarized in Tables SI-1 - SI-3. In site A, $\Delta \mathrm{h} / \Delta \mathrm{t}$ of wetland, groundwater, and stream showed strong correlations. Correlation coefficients of 0.8 or greater were recorded between stream (A-S1 and A-S2, denoted as site A stream points 1 and 2, respectively) and groundwater (A-G2, A-G3, A-G4, and A-G5, denoted as site A groundwater points 2, 3, 4, and 5, respectively). Correlation coefficients of 0.6 or greater between wetland (AW1 and A-W2, denoted as site A wetland points 1 and 2, respectively) and stream (A-S1 and AS2), and between wetland (A-W2) and groundwater (A-G5) were reported (Table SI-1). In contrast to site A, the correlations among different points in site B were relatively weaker. Although few points such as B-S2 versus B-G4 and B-W4 versus B-W2 had correlation coefficients of 0.7 or greater, many correlation coefficients were below 0.3 (Table SI-2). Results of site $\mathrm{C}$ were similar to that of site A. Strong correlations among wetland, groundwater, and stream were observed. Except few sampling points such as C-W1 and C-G8, many of the correlation coefficients were above 0.6 . 


\subsection{General Water Quality}

Site A

Water temperatures of the stream and the ephemeral wetland in site A were closely matched during the 3-month study period but the range of fluctuation in the wetland was greater than that in the stream (Figure 3a). The stream fluctuated between 6.2 and $13.6{ }^{\circ} \mathrm{C}\left(\Delta \mathrm{Temp}=7.4{ }^{\circ} \mathrm{C}\right)$ whereas the wetland fluctuated between 3.2 to $15.3{ }^{\circ} \mathrm{C}\left(\Delta \mathrm{Temp}=12.1{ }^{\circ} \mathrm{C}\right)$. In contrast to the temperature, the water chemistry of the stream and wetland in site A showed obvious differences. The electrical conductivity $\left(\mathrm{EC}_{25}\right)$ of the stream $\left(16.45 \pm 2.59 \mu \mathrm{S} \mathrm{cm}{ }^{-1}\right.$, average \pm standard deviation) was significantly lower ( $\mathrm{p}<0.05 ; \mathrm{n}=20 ; t$-test) than that of the wetland $\left(34.20 \pm 4.11 \mu \mathrm{S} \mathrm{cm}^{-1}\right.$; Figure $\left.3 \mathrm{~b}\right)$. A greater $\mathrm{pH}$ value $(\mathrm{p}<0.05)$ was generally observed in the stream, with an average of $6.53 \pm 0.24$, comparing to the $\mathrm{pH}$ of the wetland, which had an average of $6.12 \pm 0.11$ (Figure 3c). Dissolved oxygen (DO) in the stream was also consistently higher with nearly $100 \%$ saturation, but DO in the wetland was typically below $50 \%$ (Figure $3 \mathrm{~d}$ ). Similarly to water temperature, water quality parameters of the stream were relatively stable compared to that of the wetland. $\mathrm{EC}_{25}$ and $\mathrm{DO}$ of the stream fluctuated in a relatively narrow range $\left(\Delta \mathrm{EC}_{25}=9.5 \mu \mathrm{S} \mathrm{cm}^{-1}\right.$ and $\left.\Delta \mathrm{DO}=12.85 \%\right)$, compared to those in the wetlands $\left(\Delta \mathrm{EC}_{25}=\right.$ $13.5 \mu \mathrm{S} \mathrm{cm}^{-1}$ and $\left.\Delta \mathrm{DO}=43.6 \%\right)$. To eliminate the effects of temporal variation, the differences of daily measurements between stream $\left(\mathrm{X}_{1}\right)$ and wetland $\left(\mathrm{X}_{2}\right)$ at each sampling event were calculated, as summarized in Table SI-4. Except the temperature, all measures $(\mathrm{pH}, \mathrm{DO}$, and $\mathrm{EC}_{25}$ ) were significantly different between wetland and stream waters. For the nutrient analysis, the ephemeral wetland showed a greater DOC concentration $(\mathrm{p}<0.05)$ with an average of $4.27 \pm$ $0.29 \mathrm{mg} \mathrm{L}^{-1}$ than that in groundwater and stream but no difference in nitrogen was observed 
(Table 1). A significantly higher $\mathrm{C} / \mathrm{N}$ ratio $\left(13.38 \pm 3.04 \mathrm{~mol} \mathrm{~mol}^{-1}\right)$ was found in wetland compared to stream $\left(7.98 \pm 0.80 \mathrm{~mol} \mathrm{~mol}^{-1}\right)$ or groundwater $\left(8.62 \pm 1.25 \mathrm{~mol} \mathrm{~mol}^{-1}\right)$.

\section{Site B}

Water temperature, $\mathrm{EC}_{25}, \mathrm{pH}$, and $\mathrm{DO}$ of the stream and the ephemeral wetland in site $\mathrm{B}$ generally behaved the same as in site A (Figure SI-4). Greater temperature and $\mathrm{EC}_{25}$, but lower $\mathrm{pH}$ and DO were found in the wetland (Table SI-4). In contrast to the wetlands in sites A and C, DOC concentration in the ephemeral wetland in site B was similar to those in the stream and groundwater, with a mean of $1.74 \pm 0.11 \mathrm{mg} \mathrm{L}^{-1}$. The $\mathrm{C} / \mathrm{N}$ ratio in the wetland was less than 10 mol mol ${ }^{-1}$ and was not significantly different $(\mathrm{p}>0.05)$ from that in the stream. Notably, the wetland in site B was located in an open area with fewer trees in the surrounding landscape. In addition, water quality of a nearby connected wetland (Figure SI-2) was compared to that of the ephemeral wetland, and the results are summarized in Figure SI-5. The water quality between two wetlands had very similar patterns and values, although the ephemeral wetland generally had lower $\mathrm{EC}_{25}, \mathrm{pH}$, and DO. TN, $\mathrm{NO}_{3}-\mathrm{N}, \mathrm{NH}_{4}-\mathrm{N}$, and DOC concentrations of the connected wetland were similar to the ephemeral wetland and their differences were insignificant $(\mathrm{p}>0.05$; Tables 1 and 2). Although the connected wetland had obvious surface water connection with the nearby water bodies, obvious water movement was not observed. Its chemistry was quite similar to that of the ephemeral wetland.

\section{Site C}

In spite of the differences in surface area and water depth, the general water quality of the ephemeral wetland in site $\mathrm{C}$ was similar to those in sites $\mathrm{A}$ and $\mathrm{B}$. The temperature of the 
ephemeral wetland was significantly higher $(\mathrm{p}<0.05)$ than that of the stream water, with a mean of $2.24{ }^{\circ} \mathrm{C}$ difference (Table SI-4). The $\mathrm{pH}$ of the wetland $(6.72 \pm 0.23)$ was generally lower than that of the stream water $(7.42 \pm 0.36)$. The $\mathrm{EC}_{25}$ of the wetland was greater with an average of $66 \pm 12 \mu \mathrm{S} \mathrm{cm}^{-1}$. The stream $\mathrm{EC}_{25}$ was only $37 \pm 4 \mu \mathrm{S} \mathrm{cm}^{-1}$. However, the difference in $\mathrm{EC}_{25}$ was not statistically significant $(\mathrm{p}>0.05)$ due to its greater fluctuation (Figure SI-6). DO of the stream water was very stable with nearly $100 \%$ saturation whereas the wetland's DO was generally below $50 \%$. The wetland in site $\mathrm{C}$ had the highest DOC concentration among all water bodies in this study, with a mean of $6.54 \pm 2.17 \mathrm{mg} \mathrm{L}^{-1}$. Notably, groundwater in site $\mathrm{C}$ had the highest total nitrogen concentration, dominated with $\mathrm{NO}_{3}-\mathrm{N} 0.71 \pm 0.22 \mathrm{mg} \mathrm{L}^{-1}$ ) but also a significant portion of $\mathrm{NH}_{4}-\mathrm{N}\left(0.59 \pm 0.01 \mathrm{mg} \mathrm{L}^{-1}\right)$. Stream water in this site, which was a $2^{\text {nd }}$ order stream, also had a substantial level of $\mathrm{NO}_{3}-\mathrm{N}\left(0.32 \pm 0.01 \mathrm{mg} \mathrm{L}^{-1}\right)$. In contrast to water in the ephemeral wetland, dissolved organic $\mathrm{N}$, as calculated by subtracting $\mathrm{TN}$ from $\mathrm{NO}_{3}-\mathrm{N}$ and $\mathrm{NH}_{4}-\mathrm{N}$, was the major nitrogen species.

\subsection{Optical Properties of DOM}

The ephemeral wetland in sites A and C had significantly greater SUVA values $(\mathrm{p}<0.05)$ than that of stream and groundwater. In site B, no differences were observed in SUVA among three water bodies. The E2/E3 ratio and spectral slope $\left(S_{R}\right)$, which are considered surrogate of molecular weight or size of DOM (Helms et al., 2008; Loiselle et al., 2009), showed no statistical differences $(\mathrm{p}>0.05)$ among stream, groundwater, and wetlands in all three sites (Table 2). Noticeably, E2:E3 and $S_{R}$ could not be calculated when DOC concentration was too low and absorbance greater than $300 \mathrm{~nm}$ could not be detected, such as the groundwater in sites 
A and B. However, lower SUVA but higher E2/E3 values in waters collected in January were generally observed when comparing to those collected in March.

The fluorescence EEMs of stream, groundwater, and wetland in site A are shown in Figure 4. All waters showed a strong peak in the areas of excitation $(\mathrm{Ex})<240 \mathrm{~nm}$ and $400 \mathrm{~nm}<$ emission (em) $<500 \mathrm{~nm}$, representing fulvic acid-like compounds. Both stream and wetland waters showed a small peak in Ex $=280 \mathrm{~nm}$ and $\mathrm{Em}=250 \mathrm{~nm}$, indicating humic-acid like compounds. This humic-acid like peak was not obvious in groundwater. In contrast, stream and groundwater showed signals in the region of Ex $<240 \mathrm{~nm}$ and $300 \mathrm{~nm}<\mathrm{Em}<400 \mathrm{~nm}$, which are considered aromatic protein-like regions. This protein-like peak was very weak in wetlands. A fluorescence regional integration (FRI) using Simpson's rule (Zhou et al., 2013) was applied to quantify the relative abundance of these fractions, and the results of the monthly samples in site A were summarized in Figure 5. Fulvic acid-like compounds were the dominated fraction in stream and wetland waters, representing 56 and $42 \%$, respectively. Only $28 \%$ of fulvic acid-like compound was found in groundwater. Groundwater was dominated by aromatic protein compounds, which represent $49 \%$ of total DOM. Wetland water had the highest humic-like compounds, with $17 \%$, followed by the stream (12\%) and groundwater (10\%). The distributions of these 5 operationally defined fractions only slightly changed in the 3-month study period. The increase of aromatic protein region but decrease in fulvic and humic acid-like fractions were observed in wetland and stream waters from January to March. The fraction distribution in groundwater was relatively stable in the 3 months.

\section{Discussion}




\subsection{Physical Settings of Ephemeral Wetlands}

The size of a wetland (i.e., surface area and water depth) plays a significant role in determining its water and habitat qualities (Kaplan et al. 2011; Cosentino et al. 2010). The buffer capacity against environmental changes is proportional to the volume of water within an isolated wetland (Brinson 1993). In our study, a greater fluctuation in water quality in these small wetlands, such as temperature and $\mathrm{EC}_{25}$, was generally observed compared to their adjacent water bodies. The differences in water temperature became obvious in warmer conditions (i.e., April). A higher temperature, with a range of $1-5{ }^{\circ} \mathrm{C}$, was generally recorded in wetlands compared to stream and groundwater. Salt accumulation, as indicated with $\mathrm{EC}_{25}$, also became obvious at the end of season. Consider the smallest wetland in site A as an example. Its surface area was $6.75 \mathrm{~m}^{2}$ and water depth was $0.4 \mathrm{~m}$, and the water volume was about $2.7 \mathrm{~m}^{3}$. The specific heat capacity of water is $4.1885 \mathrm{~J} \mathrm{~g}^{-1} \mathrm{~K}^{-1}$ and the solar energy dose of one full, clear, summer day at latitude 36 ${ }^{\circ} \mathrm{N}$ is $14,031 \mathrm{~kJ} \mathrm{~m}^{-1}$, the temperature could raise $8.4{ }^{\circ} \mathrm{C}$ in a day (without considering evaporation and other heat exchange processes). A higher water temperature can enhance water evaporation, drying, and salt accumulation. Therefore, the $\mathrm{EC}_{25}$ of an ephemeral wetland generally increased at the end of the wet season. For example, an $\mathrm{EC}_{25}$ of over $60 \mu \mathrm{S} \mathrm{cm}-1$ was recorded in the ephemeral wetland at site B, three times higher than the level recorded in February $\left(\sim 20 \mu \mathrm{S} \mathrm{cm}^{-1}\right.$; Figure SI-4b). In addition, air-water exchange in the static water condition of these ephemeral wetlands was minimal. With relatively rich nutrient inputs from foliar litters, low DO below 50\% saturation was commonly observed.

The surrounding vegetation may also affect water quality because foliar litter is considered as an important nutrient source of isolated wetlands (Battle and Golladay, 2007; Crawford et al. 2007; 
Chow et al. 2013). In this study, the lowest DOC concentration $\left(1.74 \pm 0.11 \mathrm{mg} \mathrm{L}^{-1}\right)$ and SUVA $\left(1.87 \pm 0.78 \mathrm{~L} \mathrm{mg}^{-1} \mathrm{~m}^{-1}\right)$ were observed in the ephemeral wetland at site $\mathrm{B}$, which was located in an open area without canopy coverage. Input of foliar litters to this wetland system was minimal. In contrast, the two wetlands in sites $\mathrm{A}$ and $\mathrm{C}$ were surrounded with deciduous trees, resulting in greater DOC concentrations and $\mathrm{C} / \mathrm{N}$ ratios released from foliar litters in the wetlands.

\subsection{Biogeochemical Characteristics}

The quality and quantity of foliar litters in a wetland are important factors influencing water quality and biogeochemical processes (Rejmankova and Houdkova, 2006; Bastviken et al. 2007). Lower $\mathrm{pH}$ and DO were observed in the ephemeral wetlands compared to their adjacent water bodies, and may be attributed to the decomposition of foliar litter (Deano and Robinson, 1985; Chow et al. 2013). Different carbon fractions released from decaying leaves increased the DOC concentration and $\mathrm{C} / \mathrm{N}$ ratio in the wetland waters (Currie and Aber, 1997; Chow et al. 2011). Some of these degradable compounds such as polysaccharides and protein were found to enhance microbial activities, resulting in low DO in the wetlands (Howitt et al., 2007). Optical properties analyzed using SUVA and FRI showed that water contained significant portions of humic acid-like and fulvic acid-like compounds (Zhou et al. 2013). Dissolved organic nitrogen (DON) was the dominant $\mathrm{N}$ species (> 50\%) followed by $\mathrm{NH}_{4}-\mathrm{N}$, suggesting $\mathrm{N}$ mineralization or nitrification was minimal within the wetlands.

Most of the litter inputs occurred prior to January but the breakdown of these organic matters

through invertebrate or microbial decomposition could have been limited due to the low temperature condition in winter time. From January to March, the nutrient concentration, 
including DOC and TDN were relatively stable and no obvious changes occurred in the three months. However, a decrease of humic acid-like and fulvic acid-like fractions was observed from January to March, but an increase of aromatic protein and microbial byproduct-like fractions in the ephemeral wetlands was observed (Figure 5). The changes in DOM composition but not quantity could probably be attributed to the effects of temperature and sunlight (Chow et al., 2006; Chow et al., 2013). In January, temperature was generally $<10{ }^{\circ} \mathrm{C}$ and the biological decomposition should be minimal. In contrast, opened canopy after litter fall allowed sunlight penetration onto the wetlands. DOM could be degraded from large aromatic molecules to small water soluble non-aromatic compounds through photobleaching processes (Brinkmann et al. 2003; Chow et al. 2013). Lower SUVA but higher E2/E3 values in waters collected in January were generally observed when comparing to those collected in March. With a shallow water depth, photochemical processes could be an important process controlling nutrient cycling within the ephemeral wetlands in winter time (Piccini et al. 2009).

\subsection{Soil Infiltration}

Changes in water levels $(\Delta \mathrm{h} / \Delta \mathrm{t})$ have been used to characterize hydrological connectivity of riparian wetlands with adjacent water bodies (Cabezas et al. 2011). The rapid and simultaneous changes in water levels during rainstorm events suggested the hydrological connectivity of the ephemeral wetlands with the surrounding water bodies. Considering site A as an example (Figure 2), sudden increases of water levels in groundwater and wetland were observed with intensive rainstorms (> $0.5 \mathrm{~mm}$ per day). Notably, the water levels promptly dropped back to their background levels in only 1-2 days. Water loss of a completely isolated wetland should be through evaporation only and their water levels should be relatively stable in such low 
temperature condition ( $\mathrm{T}<15{ }^{\circ} \mathrm{C}$ during the study period). The decrease in water levels in such a short time indicated that water seeped out to the surrounding areas rather than being lost due to evaporation. In fact, the water level peaks of wetlands closely matched the peaks of groundwater. The strong correlations in $\Delta \mathrm{h} / \Delta \mathrm{t}$ among water bodies further support this argument (Tables SI-1 - SI-3).

In spite of their potential hydrological connectivity, the water quality of the ephemeral wetlands differed from their adjacent water bodies. Distinguishable temperature, $\mathrm{pH}, \mathrm{DO}, \mathrm{DOM}$, and nutrients were found among different water bodies (Tables 1, 2 and SI-4). Such biogeochemical disconnection among water bodies could occur over even a short distance as long as there was no direct surface water connection. For example, the ephemeral wetland in site A was $10.7 \mathrm{~m}$ away from the $1^{\text {st }}$ order stream. Despite the short distance between the ephemeral wetland and the $1^{\text {st }}$ order stream and the hydrological connectivity suggested by the changes in water level (i.e. $\Delta \mathrm{h} / \Delta \mathrm{t}$ ), their water chemistry was significantly different from each other. The biogeochemical disconnection was attributed to the soil infiltration process. Soil between the two water bodies served as a chemical filter that could absorb and reduce nutrients and minimize the chemical mixing between two water bodies (Parsons et al. 2004; Chow et al. 2009; Schmidt et al. 2012). Furthermore, soil has been demonstrated to effectively remove organic matter from water through filtration processes (Maeng et al. 2008; Mudarra et al. 2011). Soil acting as sorbents can absorb certain DOM fractions, particularly hydrophobic fractions, and reduce the DOC concentration passing through the soil columns. A significant decrease in UV/VIS absorbance from wetland water to groundwater was recorded. FRI and SUVA analyses also demonstrated 
that the humic acid-like compounds, the major fraction found in wetlands, were not observed in groundwater (Figure 5).

In addition to serving as a chemical filter, soil can serve as a bioreactor altering the biogeochemical processes and nutrient cycling such as natural organic matter degradation and denitrification (Diem et al., 2013). Consider N species along a potential water connection (i.e. wetland $\leftrightarrow \rightarrow$ groundwater $\leftrightarrow \rightarrow$ stream). Wetlands were dominated with dissolved organic nitrogen (DON) because of leachate from foliar litter. Microbial processes in the soil could convert DON into inorganic $\mathrm{N}$ through mineralization when wetland waters seeped to groundwater (Wolf et al., 2013). As shown in groundwater in site C, it was dominated by inorganic $\mathrm{N}$ with similar portions of $\mathrm{NH}_{4}-\mathrm{N}$ and $\mathrm{NO}_{3}-\mathrm{N}$. This inorganic $\mathrm{N}$ was further processed through nitrification when water exported to the stream (Racchetti et al., 2011). As seen in the $2^{\text {nd }}$ order stream in site $\mathrm{C}$, nitrate was the only dominate species. Differences in $\mathrm{N}$ species demonstrated that ephemeral wetlands, groundwater, and the stream had unique water chemistry or were biogeochemically distinct in spite of their proximity.

\section{Conclusion}

Water chemistry and physical parameters of three ephemeral wetlands and their adjacent water bodies in the Piedmont ecoregion were monitored during their flooded period in 2012. Nutrient and water quality analyses indicated their chemistries differed. Lower $\mathrm{pH}$ and DO were observed in ephemeral wetlands we believe because of foliar litter decomposition, while higher $\mathrm{EC}_{25}$ and temperature fluctuations were recorded most likely because smaller wetlands were less buffered against environmental changes. A higher DOC concentration with a significant portion 
of humic acid-like and fulvic-acid like compounds was found in ephemeral wetlands. Also, dissolved organic $\mathrm{N}$ was the dominant $\mathrm{N}$ species in wetlands. Soil infiltration processes most likely altered the water chemistry, reducing the DOC concentration and converting organic nitrogen into inorganic nitrogen in groundwater and stream water. The groundwater connections coupled with the lack of biogeochemical similarity among the ephemeral wetlands and the permanent water bodies suggest that the ephemeral wetlands not only contribute to groundwater recharge, but soils surrounding the ephemeral wetlands contribute to the maintenance of the chemical integrity of the groundwater.

\section{Acknowledgments}

Funding was provided by the US Environmental Protection Agency Region IV WPDG and Sustainable Forestry Initiative, Inc. Field and logistical support was provided by the South Carolina Department of Natural Resources, Joseph J. Tavano, Knight Cox, and Clemson University undergraduate and graduate students. This research is also based on the work supported by a NIFA/USDA grant under project number SC-1700489. The paper is technical contribution number No. 6288 of the Clemson University Experimental Station.

\section{References}

Bastviken SK, Eriksson PG, Ekstrom A, Tonderski K (2007) Seasonal denitrification potential in wetland sediments with organic matter from different plant species. Water Air Soil Poll 183(1-4): 25-35

Battle JM, Golladay SW (2007) How hydrology, habitat type, and litter quality affect leaf breakdown in wetlands on the gulf coastal plain of Georgia. Wetlands 27(2): 251-260 
Brinkmann T, Horsch P, Sartorius D, Frimmel FH (2003) Photoformation of low-molecularweight organic acids from brown water dissolved organic matter. Environ Sci Technol 37(18): 4190-4198

Brinson MM (1993) Changes In the Functioning Of Wetlands Along Environmental Gradients. Wetlands 13(2): 65-74

Cabezas A, Gonzalez-Sanchis M, Gallardo B, and Comin FA (2011) Using continuous surface water level and temperature data to characterize hydrological connectivity in riparian wetlands. Environmental Monitoring and Assessment 183(1-4): 485-500.

Campbell CE, Allen J, Lu KS (2008) Modeling growth and predicting future developed land in the Upstate of South Carolina. In: Proceedings of the 2008 South Carolina Water Resources Conference. vol August. Clemson University Restoration Institute, Clemson, SC.

Chow AT, Dahlgren RA, Zhang Q, Wong PK (2008) Relationships between specific ultraviolet absorbance and trihalomethane precursors of different carbon sources. J. Water Supply Res. T. 57(7): 471-480

Chow AT, Dai JN, Conner WH, Hitchcock DR, Wang JJ (2013) Dissolved organic matter and nutrient dynamics of a coastal freshwater forested wetland in Winyah Bay, South Carolina. Biogeochemistry 112(1-3): 571-587

Chow AT, O'Geen AT, Dahlgren RA, Diaz F, Wong KH, and Wong PK (2011) Reactivity of foliar litter leachates from California Oak woodlands in the formation of disinfection Byproducts. Journal Environmental Quality 40: 1607-1616.

Chow AT, Lee ST, O'Geen AT, Orozco T, Beaudette D, Wong PK, Hernes PJ, Tate KW, Dahlgren RA (2009) Litter contributions to dissolved organic matter and disinfection 
byproduct precursors in California oak woodland watersheds. J Environ Qual 38(6): $2334-2343$

Chow AT, Tanji KK, Gao SD, Dahlgren RA (2006) Temperature, water content and wet-dry cycle effects on DOC production and carbon mineralization in agricultural peat soils. Soil Biol. Biochem. 38(3): 477-488

Cosentino BJ, Schooley RL, Phillips CA (2010) Wetland hydrology, area, and isolation influence occupancy and spatial turnover of the painted turtle, Chrysemys picta. Landscape Ecol 25(10): $1589-1600$

Crawford ER, Day FP, Atkinson RB (2007) Influence of environment and substrate quality on root decomposition in naturally regenerating and restored Atlantic white cedar wetlands. Wetlands 27(1): 1-11

Currie WS, Aber JD (1997) Modeling leaching as a decomposition process in humid Montane forests. Ecology 78(6): 1844-1860

Dalrymple RM, Carfagno AK, Sharpless CM (2010) Correlations between Dissolved Organic Matter Optical Properties and Quantum Yields of Singlet Oxygen and Hydrogen Peroxide. Environ Sci Technol 44(15): 5824-5829

Deano PM, Robinson JW (1985) The effect of decaying leaves on the pH and buffer capacity of waters. Journal of Environ Sci and Health Part A - Environ Sci and Engineering 20(8): 903-911.

Diem S, Rudolf von Rohr M, Hering JG, Kohler H-PE, Schirmer M, von Gunten U (2013) NOM degradation during river infiltration: Effects of the climate variables temperature and discharge. Water Research 47(17): 6585-6595 
Eaton AD, Franson MAH (2005) Standard Methods for the Examination of Water \& Wastewater. Amer Public Health Assn, Washington, D.C.

Federal Register (2014) Definition of Waters of the United States Under the Clean Water Act. 79 FR 22187. Website: https://www.federalregister.gov/articles/2014/04/21/201407142/definition-of-waters-of-the-united-states-under-the-clean-water-act

Gibbons JW, Scott DE, Ryan STJ, BuhlamnnKA, Tuberville TD, Metts BS, Greene JL, Mills T, Leiden Y, Poppy S, and Winne CT (2000) The global decline of reptiles, Deja Vu amphibians. Bioscience 50:653-666

Gibbs JP (1993) Importance of small wetlands for the persistence of local populations of wetland-associated animals. Wetlands 13:25-31

Glinska-Lewczuk K (2009) Water quality dynamics of oxbow lakes in young glacial landscape of NE Poland in relation to hydrological connectivity. Ecological Engineering 35(1): 2537.

Golden HE, Lane CR, Amatya DM, Bandilla KW, Kiperwas HR, Knightes CD, and Ssegane H (2014) Hydrologic connectivity between georgraphically isolated wetlands and surface water systems: A review of select modeling methods. Environ Model \& Software 53: 190-206.

Grumbles BH, Woodley J, John Paul (2008) Clean Water Act jurisdiction following the U.S. Supreme Court's decision in Rapanos v. United States \& Carabell v. United States. In., http://water.epa.gov/lawsregs/guidance/wetlands/CWAwaters.cfm.

Helms JR, Stubbins A, Ritchie JD, Minor EC, Kieber DJ, Mopper K (2008) Absorption spectral slopes and slope ratios as indicators of molecular weight, source, and photobleaching of chromophoric dissolved organic matter. Limnol Oceanogr 53(3): 955-969 
Howitt JA, Baldwin DS, Rees GN, Williams JL (2007) Modelling blackwater: Predicting water quality during flooding of lowland river forests. Ecol Model 203(3-4): 229-242

Jenkins DG, Grissom C, Miller K (2003) Consequences of prairie wetland drainage for crustacean biodiversity and metapopulations. Conservation Biology 17:158-167

Kaplan D, Bachelin M, Muoz-Carpena R, Chacon WR (2011) Hydrological importance and water quality treatment potential of a small freshwater wetland in the humid tropics of Costa Rica. Wetlands 31(6): 1117-1130

Leibowitz SG (2003) Isolated wetlands and their functions: an ecological perspective. Wetlands 23:517-531

Loiselle SA, Bracchini L, Dattilo AM, Ricci M, Tognazzi A, Cozar A, Rossi C (2009) Optical characterization of chromophoric dissolved organic matter using wavelength distribution of absorption spectral slopes. Limnol Oceanogr 54(2): 590-597

Maeng SK, Sharma SK, Magic-Knezev A, Amy G (2008) Fate of effluent organic matter (EfOM) and natural organic matter (NOM) through riverbank filtration. Water Sci Technol 57(12): 1999-2007

Moreno-Mateos D, Power ME, Comin FA, Yockteng R (2012) Structureal and functional loss in restored wetland ecosystems. Plos Biology 10(1): e1001247

Mudarra M, Andreo B, Baker A (2011) Characterisation of dissolved organic matter in karst spring waters using intrinsic fluorescence: Relationship with infiltration processes. Sci Total Environ 409(18): 3448-3462

Napton DE, Auch RF, Headley R, Taylor JL (2010) Land changes and their driving forces in the southeastern United States. Regional Environmental Change 10: 37-53 
Obolewski K (2011) Macrozoobenthos patterns along environmental gradients and hydrological connectivity of oxbow lakes. Ecological Engineering 37(5): 796-805.

Osburn CL, Handsel LT, Mikan MP, Paerl HW, Montgomery MT (2012) Fluorescence tracking of dissolved and particulate organic matter quality in a river-dominated estuary. Environ Sci Technol 46(16): 8628-8636

Racchetti E, Bartoli M, Soana E, Longhi D, Christian R, Pinardi M, Viaroli P. 2011. Influence of hydrological connectivity of riverine wetlands on nitrogen removal via denitrification. Biogeochemistry 103:335 - 354

Piccini C, Conde D, Pernthaler J, Sommaruga R (2009) Alteration of chromophoric dissolved organic matter by solar UV radiation causes raid changes in bacterial community composition. Photochem \& Photobiol Sci 8(9): 1321-1328.

Parsons DF, Hayashi M, van der Kamp G (2004) Infiltration and solute transport under a seasonal wetland: bromide tracer experiments in Saskatoon, Canada. Hydrol Process 18(11): 2011-2027

Pitt AL, Baldwin RF, Lipscomb DJ, Brown BL, Hawley JE, Allard-Keese CM, Leonard PB (2012) The missing wetlands: using local ecological knowledge to find cryptic ecosystems. Biodivers Conserv 21(1): 51-63

Rejmankova E, Houdkova K (2006) Wetland plant decomposition under different nutrient conditions: what is more important, litter quality or site quality? Biogeochemistry 80(3): $245-262$

Robinson JW, Deano PM (1985) The Synergistic Effects of acidity and aluminum on fish (Golden Shiners) In Louisiana. J Environ Sci Heal A 20(2): 193-204 
Schmidt CM, Fisher AT, Racz A, Wheat CG, Los Huertos M, Lockwood B (2012) Rapid nutrient load reduction during infiltration of managed aquifer recharge in an agricultural groundwater basin: Pajaro Valley, California. Hydrol Process 26(15): 2235-2247

Wolf KL, Noe GB, and Ahn C (2013) Hydrological connectivity to streams increases nitrogen and phosphorus inputs and cycling in soils of created and natural floodplain wetlands. Journal of Environmental Quality 42(4): 1245-1255.

Zedler PH (2003) Vernal pools and the concept of "isolated wetlands". Wetlands 23(3): 597-607

Zedler JB and Kercher S (2005) Wetland resources: status, trends, ecosystem services, and restorability. Annual Review of Environmental Resources 30:39-74

Zhou J, Wang JJ, Baudon A, Chow AT (2013) Improved fluorescence excitation-emission matrix regional integration to quantify spectra for fluorescent dissolved organic matter. $\mathrm{J}$ Environ Qual 42(3): 925-930 
Table 1. Comparison of monthly nutrient concentrations (mean \pm standard deviation, $n \geq 6$ )

among different water bodies in sites A, B, and C. Means with different superscript letter (a, b, and $c)$ in the same row indicate the difference is statistically significant $(\mathrm{p}<0.05)$. All concentrations units are in $\mathrm{mg} \mathrm{L}^{-1}$, except $\mathrm{C} / \mathrm{N}$ ratio, which are expressed in mol $\mathrm{mol}^{-1} . \mathrm{NP}=$ using non-parametric comparison as the normality tests did not pass.

Table a-site A

\begin{tabular}{llcc}
\hline Parameters & Stream & Groundwater & Ephemeral Wetland \\
\hline DOC $^{\mathrm{NP}}$ & $1.73 \pm 0.22^{\mathrm{b}}$ & $1.32 \pm 0.18^{\mathrm{a}}$ & $4.27 \pm 0.29^{\mathrm{c}}$ \\
Total Nitrogen $^{\mathrm{NP}}$ & $0.21 \pm 0.12^{\mathrm{a}}$ & $0.18 \pm 0.03^{\mathrm{a}}$ & $0.27 \pm 0.19^{\mathrm{a}}$ \\
$\mathrm{NH}_{4}-\mathrm{N}^{\mathrm{NP}}$ & $0.05 \pm 0.04^{\mathrm{a}}$ & $0.03 \pm 0.02^{\mathrm{a}}$ & $0.05 \pm 0.04^{\mathrm{a}}$ \\
$\mathrm{NO}_{3}-\mathrm{N}$ & $0.05 \pm 0.02^{\mathrm{b}}$ & $0.02 \pm 0.01^{\mathrm{a}}$ & $0.02 \pm 0.01^{\mathrm{a}}$ \\
$\mathrm{C} / \mathrm{N}^{\mathrm{NP}}$ & $7.98 \pm 0.80^{\mathrm{a}}$ & $8.62 \pm 1.25^{\mathrm{a}}$ & $13.38 \pm 3.04^{\mathrm{b}}$ \\
\hline
\end{tabular}

Table b-site B

\begin{tabular}{lllcc}
\hline Parameters & Stream & Groundwater & Ephemeral Wetland & Connected Wetland \\
\hline DOC & $1.97 \pm 0.03^{\mathrm{b}}$ & $1.94 \pm 0.12^{\mathrm{b}}$ & $1.74 \pm 0.11^{\mathrm{a}}$ & $2.14 \pm 0.07^{\mathrm{c}}$ \\
Total Nitrogen & $0.24 \pm 0.15^{\mathrm{a}}$ & $0.56 \pm 0.10^{\mathrm{b}}$ & $0.25 \pm 0.04^{\mathrm{a}}$ & $0.39 \pm 0.19^{\mathrm{b}}$ \\
$\mathrm{NH}_{4}-\mathrm{N}^{\mathrm{NP}}$ & $0.09 \pm 0.06^{\mathrm{a}}$ & $0.49 \pm 0.26^{\mathrm{b}}$ & $0.11 \pm 0.15^{\mathrm{a}}$ & $0.12 \pm 0.02^{\mathrm{a}}$ \\
$\mathrm{NO}_{3}-\mathrm{N}^{\mathrm{NP}}$ & $0.03 \pm 0.02^{\mathrm{a}}$ & $0.09 \pm 0.17^{\mathrm{a}}$ & $0.01 \pm 0.0^{\mathrm{a}}$ & $0.01 \pm 0.01^{\mathrm{a}}$ \\
$\mathrm{C} / \mathrm{N}^{\mathrm{NP}}$ & $7.37 \pm 2.60^{\mathrm{ab}}$ & $4.00 \pm 2.29^{\mathrm{a}}$ & $8.54 \pm 0.96^{\mathrm{b}}$ & $5.73 \pm 2.06^{\mathrm{ab}}$ \\
\hline
\end{tabular}

Table c-site C

\begin{tabular}{lccc}
\hline Parameters & Stream & Groundwater & Ephemeral Wetland \\
\hline DOC & $1.71 \pm 0.09^{\mathrm{a}}$ & $3.62 \pm 0.45^{\mathrm{b}}$ & $6.54 \pm 2.17^{\mathrm{c}}$ \\
Total Nitrogen $^{\mathrm{NP}}$ & $0.39 \pm 0.15^{\mathrm{a}}$ & $1.47 \pm 0.19^{\mathrm{b}}$ & $0.46 \pm 0.36^{\mathrm{a}}$ \\
$\mathrm{NH}_{4}-\mathrm{N}^{\mathrm{NP}}$ & $0.04 \pm 0.01^{\mathrm{a}}$ & $0.59 \pm 0.01^{\mathrm{b}}$ & $0.15 \pm 0.15^{\mathrm{a}}$ \\
$\mathrm{NO}_{3}-\mathrm{N}^{\mathrm{NP}}$ & $0.32 \pm 0.04^{\mathrm{a}}$ & $0.71 \pm 0.22^{\mathrm{a}}$ & $0.01 \pm 0.01^{\mathrm{b}}$ \\
$\mathrm{C}^{\mathrm{N}}$ & $5.98 \pm 2.63^{\mathrm{a}}$ & $4.60 \pm 2.93^{\mathrm{a}}$ & $11.11 \pm 1.32^{\mathrm{b}}$ \\
\hline
\end{tabular}


Table 2. Comparison of monthly optical properties of DOM (mean \pm standard deviation, $n=3$ ) among different water bodies in sites A, B, and C. Means with different superscript letter (a, b, and $c)$ in the same row indicate the difference is statistically significant $(\mathrm{p}<0.05) . \mathrm{NP}=\mathrm{using}$ non-parametric comparison. N.A. = Not applicable.

Table a - site A

\begin{tabular}{llll}
\hline Parameters & Stream & Groundwater & Ephemeral Wetland \\
\hline SUVA $^{N P}$ & $1.64 \pm 0.16^{\mathrm{b}}$ & $0.32 \pm 0.01^{\mathrm{a}}$ & $3.32 \pm 0.26^{\mathrm{c}}$ \\
E2/E3 & $3.65 \pm 0.18^{\mathrm{a}}$ & N.A. & $4.10 \pm 0.42^{\mathrm{b}}$ \\
$\mathrm{S}_{\mathrm{R}}{ }^{\mathrm{aP}}$ & $1.38 \pm 0.88^{\mathrm{b}}$ & N.A. & $0.80 \pm 0.01^{\mathrm{a}}$ \\
\hline
\end{tabular}

Table $\mathrm{b}$ - site B

\begin{tabular}{lllll}
\hline Parameters & Stream & Groundwater & Ephemeral Wetland & Connected Wetland \\
\hline SUVA & $1.81 \pm 0.21^{\mathrm{a}}$ & $1.15 \pm 0.43^{\mathrm{a}}$ & $1.87 \pm 0.78^{\mathrm{a}}$ & $1.66 \pm 0.53^{\mathrm{a}}$ \\
E2/E3 $^{\mathrm{NP}}$ & $4.00 \pm 0.43^{\mathrm{a}}$ & N.A. & $3.69 \pm 0.40^{\mathrm{a}}$ & $4.11 \pm 0.76^{\mathrm{a}}$ \\
$\mathrm{S}_{\mathrm{R}}{ }^{\mathrm{NP}}$ & $0.75 \pm 0.06^{\mathrm{a}}$ & N.A. & $0.71 \pm 0.12^{\mathrm{a}}$ & $0.76 \pm 0.10^{\mathrm{a}}$ \\
\hline
\end{tabular}

Table c - site C

\begin{tabular}{llll}
\hline Parameters & Stream & Groundwater & Ephemeral Wetland \\
\hline SUVA $^{\mathrm{NP}}$ & $2.62 \pm 0.26^{\mathrm{b}}$ & $1.17 \pm 0.70^{\mathrm{a}}$ & $4.56 \pm 1.23^{\mathrm{c}}$ \\
$\mathrm{E}_{2} / \mathrm{E} 3^{\mathrm{NP}}$ & $3.39 \pm 0.48^{\mathrm{b}}$ & $2.81 \pm 0.90^{\mathrm{a}}$ & $4.03 \pm 0.49^{\mathrm{b}}$ \\
$\mathrm{S}_{\mathrm{R}}$ & $0.69 \pm 0.10^{\mathrm{a}}$ & $1.06 \pm 0.29^{\mathrm{b}}$ & $0.70 \pm 0.10^{\mathrm{a}}$ \\
\hline
\end{tabular}



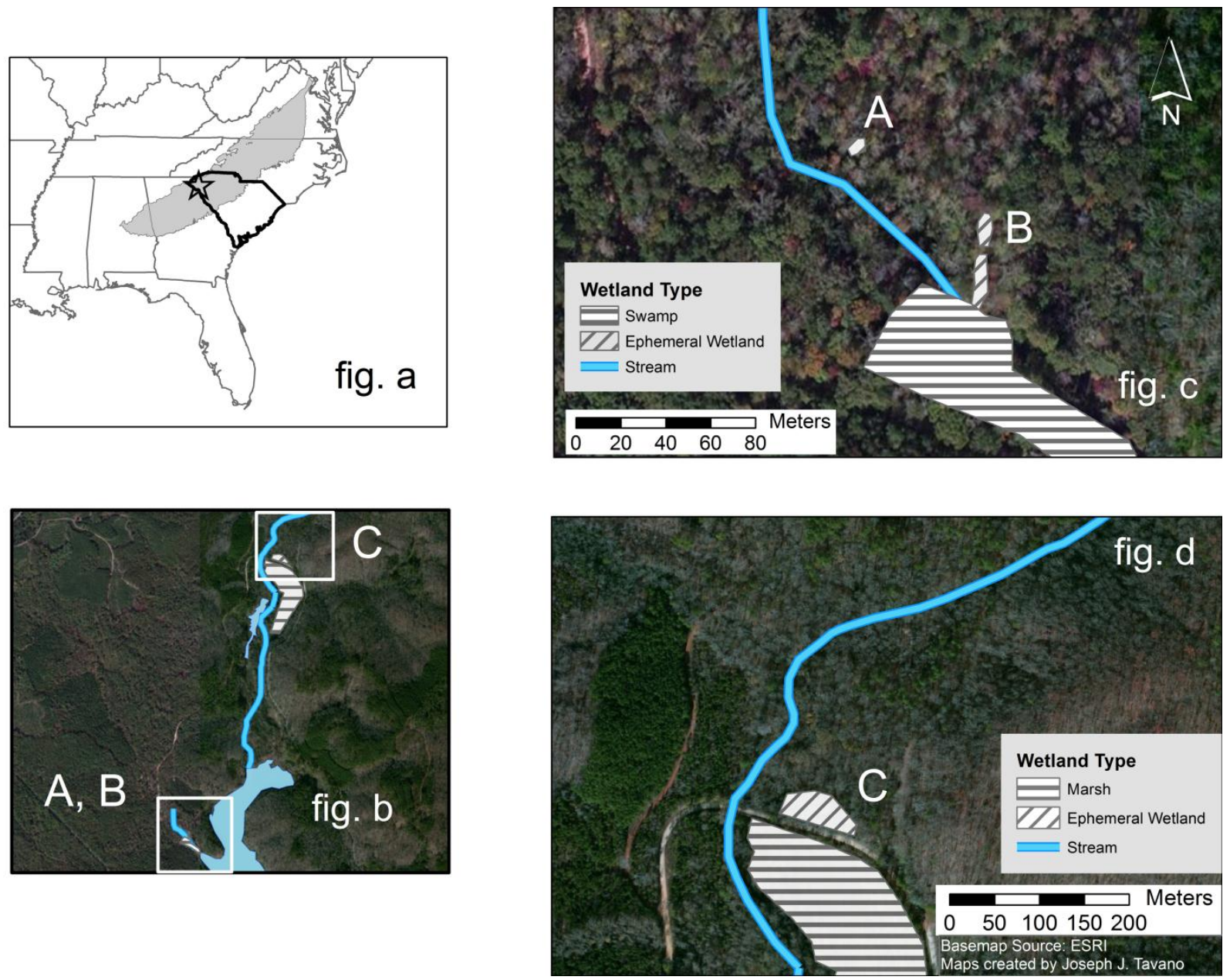

Figure 1. (a) The Piedmont ecoregion (depicted by gray) of South Carolina, USA. Star indicates the location of the study area. (b) Map of the two index landscapes used to evaluate hydrological and biogeochemical connectivity. (c) Index landscape 1 includes site A and B. (d) Index landscape 2 includes site $\mathrm{C}$. 


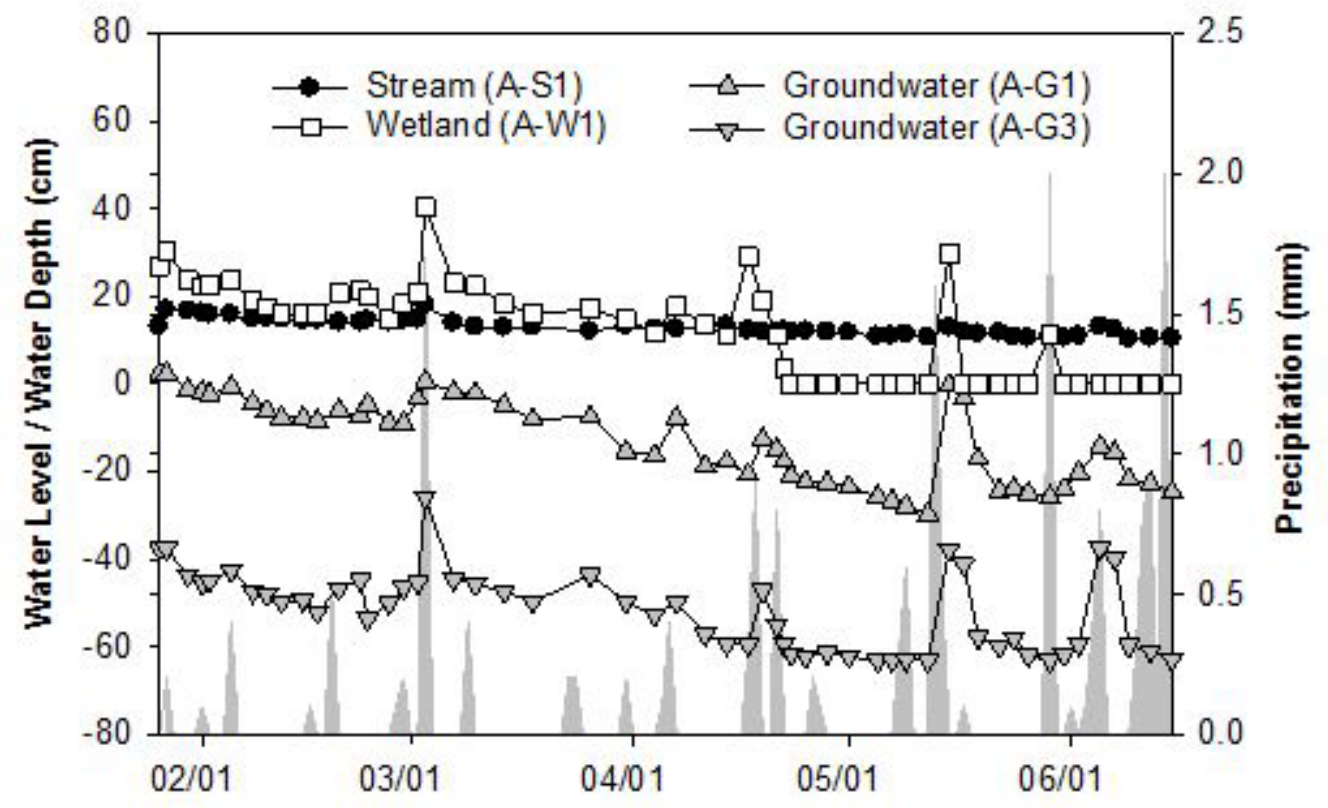

Figure 2. Water levels or depths of stream (S), wetland (W), and groundwater (G) in site A measured between 1/26/2013 and 6/15/2013. Numbers after the capitalized letters of G, S, and W denote the location of sampling points. Precipitation is depicted by the gray bars using the scale on the right-hand $\mathrm{y}$ axis. 

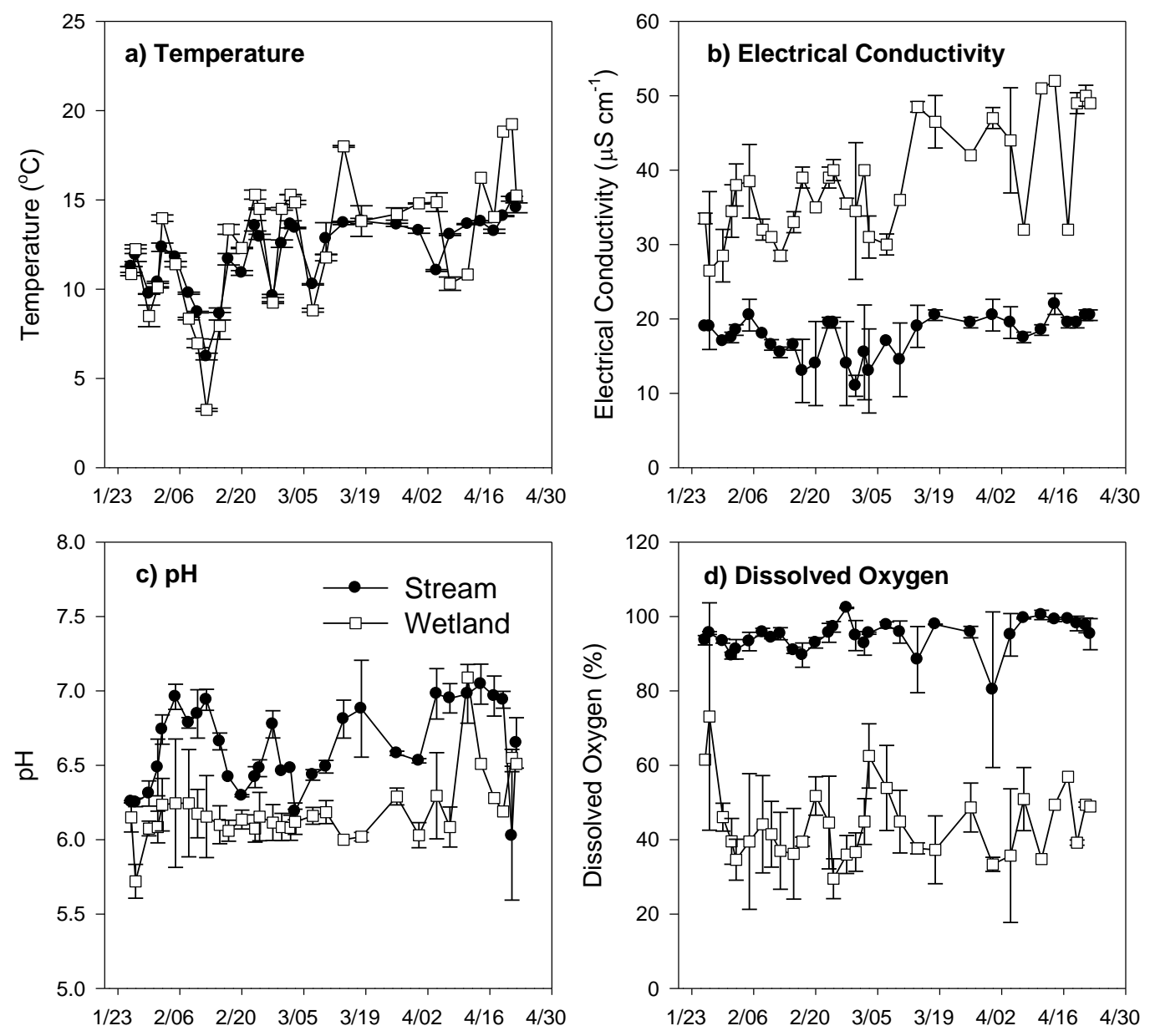

Figure 3. General water quality of ephemeral wetland and adjacent stream at site A. Water quality was determined in the wet period of the wetland between 1/26/2012 and 4/22/2012. Values and error bars are the average and the range of two measurements. 

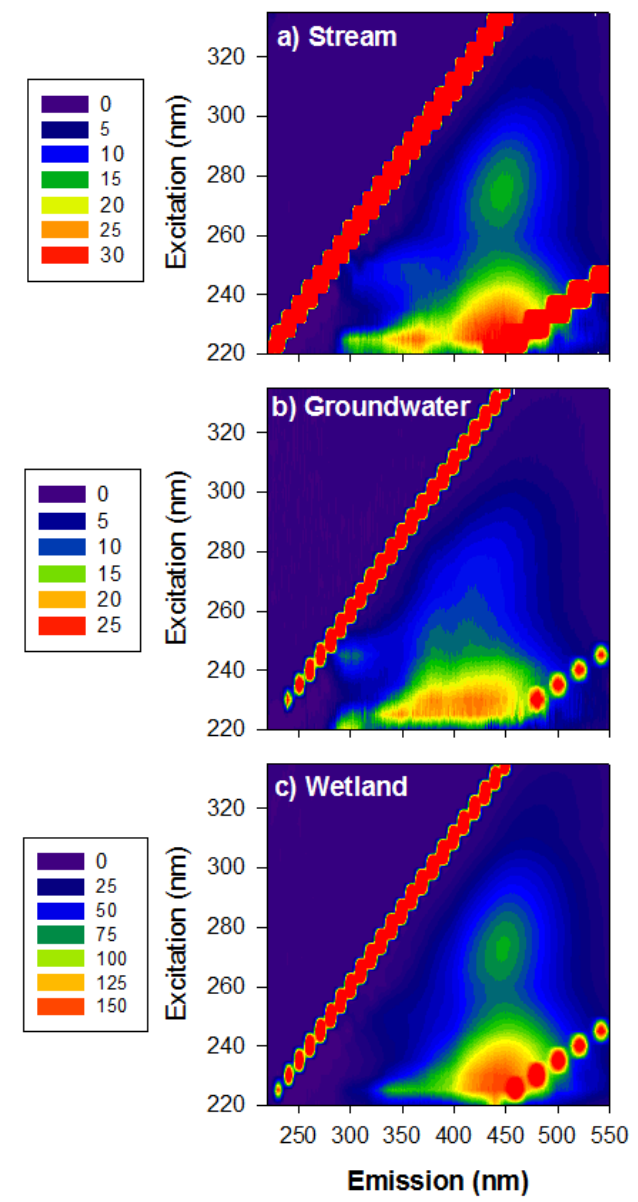

Figure 4. Fluorescence excitation-emission spectra of waters collected from stream (a), groundwater (b), and wetland (a) at site A in January 2012. 


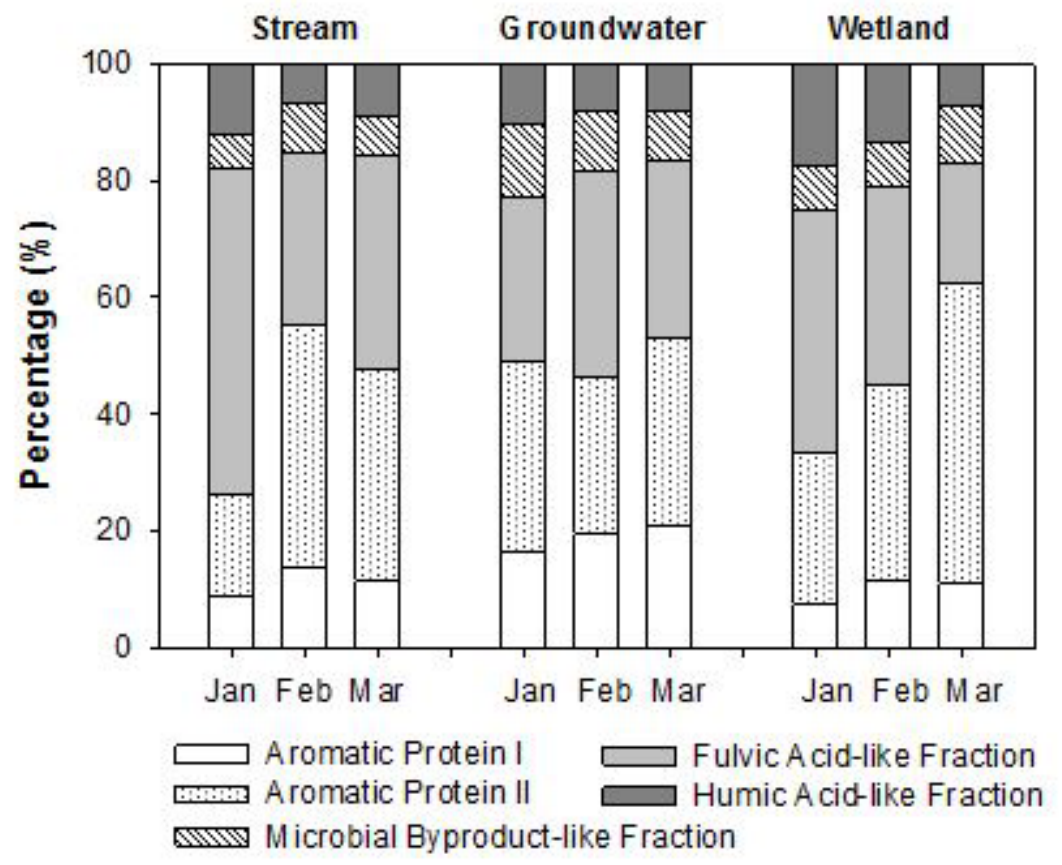

Figure 5. Fraction distributions of dissolved organic matter of three water bodies at site A. 